\title{
Hızlı kentsel değişimin doğala yakın habitatlara etkisinin değerlendirilmesi: Ankara ili Bağlıca ve Yapracık mahallesi örneği
}

\author{
Tuba KARAKAŞ (Orcid: 0000-0001-5752-6773) ${ }^{1 *}$ \\ ${ }^{1}$ Bartın Üniversitesi, Orman Fakültesi, BARTIN \\ "Sorumlu yazar/Corresponding author: yazar tubapeyzaj@gmail.com, Geliş tarihi/Received: 15.06.2017, Kabul tarihi/Accepted: 10.07.2017
}

Öz

Bu çalışmada, Ankara ili Bağlıca ve Yapracık Mahalleleri örneğinde hızlı kentsel gelişimin yaşandığı habitatlar incelenmiş, gelişen alanların verimli tarım alanları, orman parçaları, boş alanlar, ulaşım habitatları, yerleşim habitatları gibi habitatlar üzerinde bulunduğu tespit edilmiştir. Ayrıca gelişimin habitatlar üzerinde oluşturduğu baskı ve etkiler de değerlendirilmiştir. Bu çalışmada amaç, alanlarda yer alan doğal habitat gruplarını incelemek ve kentleşmenin habitatlar üzerindeki etkilerini tespit etmek, inceleme sonucunda doğal alanların korunması konusunda önlem almak ve öneriler sunmaktır. Hızlı kentsel gelişimin yaşandığı en önemli illerden biri olan Ankara'da kent merkezi çeperinde yer alan Bağlıca ve önemli tarım alanlarının yer aldığı Yapracık araştırma alanı olarak seçilmiştir.

Anahtar Kelimeler: Kent, hızlı kentsel büyüme, habitat parçalanması, Yapracık, Bağlıca.

\section{Evaluation of the effects of rapid urban change in natural habitats: Example of Bağlıca and Yapracık neighborhood in Ankara province}

\begin{abstract}
In this study, the habitats where rapid urbanization was experienced in Baglica and Yapracik neighborhoods in Ankara province was observed and it was determined that developing areas were established in such areas as fertile agricultural lands, forest fragments, free fields, transition habitats, settlement habitats. The objective of this study is to observe the natural habitat groups in these areas, to determine the impact of urbanization on habitats, to take measures for the protection of natural areas as a result of observation, and to submit proposals. Bağlica, on the periphery of the city and Yapracik, where important agricultural areas exist, are selected as research areas in Ankara.
\end{abstract}

Keywords: City, Rapid urbanization, Habitat fragmentation, Yapracık, Bağlıca.

To cite this article (Atıf): KARAKAȘ T., 2017. Hızlı kentsel değișimin doğala yakın habitatlara etkisinin değerlendirilmesi: Ankara ili Bağlıca ve Yapracık mahallesi örneği, Orman Genel Müdürlüğü Ormanc1lık Araştırma Dergisi, 4(1):77-89

DOI: https://doi.org/10.17568/ogmoad.321772

\section{Giriş}

Son yıllarda birçok ülkede olduğu gibi ülkemizde de hızla artan nüfus nedeniyle topraklar, aşırı yoğunlukta kullanılmaya başlamıştır. Zamanla kent merkezindeki nüfusun hızlı bir şekilde artmas1, kentlerin alan ihtiyacını arttırmakta olup büyüme süreciyle birlikte kentler gelişip yayılmaya başlamıştır. Kentlerin yayılması pek çok sorunu da beraberinde getirmiştir. Plansız yapılaşma ve kontrolsüz gelişme, kent çeperlerindeki doğal alanlar üzerine baskı kurmaktadır. Tarım alanları, ormanlık ve mera alanları, doğal peyzaj unsurları ve habitat grupları bu baskıdan önemli ölçüde etkilenmektedir. Gerekli tedbirler alınmadığı takdirde bu baskıların çevre açısından ciddi sorunlar yaratacağı açıktır.

Kentleşmenin en büyük sorunlarından birisi habitatın parçalanmasıdır. Fahrig (2003), habitat parçalanması genellikle habitat kaybı ve habitatın başka bir yere ayrılmasını kapsayan geniş arazi ölçeğindeki oluşum olarak tanımlamakla birlikte, bugüne kadar yapılan çalışmalar habitat kaybının biyolojik çeşitlilik üzerinde sürekli olarak olumsuz etki yaptığını ortaya koymakta olduğunu ifade etmektedir.

Tarım arazilerinin genişlemesi ve yoğunlaşması küresel çevresel değişimin önemli bir itici gücü olarak kabul edilmektedir. İnsanlar yaşamları boyunca yeryüzünün $\% 38,2$ 'sini tarım alanına dönüştürmüştür. Tarım için arazi kullanımı, dünyanın doğal yaşam alanlarının üçte birinden fazlasının kaybına yol açmıştır. Gelecek 100 yıl içerisinde g1da, lif ve yakıt üretimi için dönüşüm nedeniyle habitat kayb1 \%60'a ulaşabilecektir (Wade ve ark., 2007).

Tarımsal dönüşüm, kentleşme/banliyöleşmenin artması ile birlikte doğal ekosistemlerin ve bunların bitki ve hayvan tür bileşeni üzerinde eşi benzeri görülmemiş zorluklar meydana getirecektir (Robertson ve Swinton, 2005). 
Arazi kullanımından kaynaklı habitat kaybının ve yollardan kaynaklı habitat bölünmesinin kısmi önemi, söz konusu arazideki; habitat gereksinimleri, organizmaların yayılış kabiliyeti, yolların biçimi ve arazi kullanımları arasındaki etkileşimlere bağlıdır (Cushman ve ark., 2009).

Çalışma alanında probleminin temelinde bölgede yaşanan hızlı nüfus artışı yatmaktadır. Araştırma alanının da içinde bulunduğu Ankara-Eskişehir Çevre Yolu güzergâhındaki tarım alanlarının çoğu yerleşim alanlarının etkisi altında kalmıştır (Yakar, 2013). Hızlı gelişmenin en fazla yaşandığ 1 bölge olması, bölgenin araştırma alanı olarak seçilmesinde önemli bir rol oynamıştır. Çalışmanın amacı ise, bölgede son 70 yıl içinde yaşanan kentsel gelişmeleri inceleyerek, gelişmenin doğal habitatlara etkisinin değerlendirmesini yapmak ve yaşanacak olumsuzlara karşı alınabilecek önlemleri sunmaktır.

\subsection{Kent ve kentleşme kavramları}

Bir yerleşim biçimi ve topluluk türü olan kent, pek çok farklı şekilde tanımlanmıştır. Lois Wirt kenti şu şekilde tanımlamıştır: "Toplumsal açıdan benzer olmayan bireylerin oluşturduğu, yoğun nüfusa sahip ve mekânda devamlılığı olan yerleşmedir." Daha farklı açıdan ise, "belirli bir nüfus sınırın1 aşan, kırsal topluluklardan tamamen ayrılan yerleşim birimi” olarak tanımlanmıştır (URL-1). İdari tanımı ile kent belirli bir nüfus yoğunluğuna ulaşan yerleşim birimidir. Ekonomik açıdan kent tanımı ise, iş gücünün tarım dışı hizmetlere yani hizmet sektörü ve endüstri sektörüne transferidir (Özkan, 2011).

Kentleşme ise; "endüstri ve ekonomik gelişmelere bağlı olarak, kentlerin sayısının artmasını ve büyümesine neden olan, bireyler arasında iş paylaşımı ve örgütlenmeyi sağlayan, kırsaldan farklı olarak kente özgü değişiklikleri meydana getiren nüfus yoğunlaşma sürecidir (Ulusoy ve Vural, 2001).

Başka bir kaynakta (URL-2), kentleşmenin göstergeleri; (1) tarımın modernleşmesi, emek üretimi yerine teknolojik üretimin yaygınlaşması, (2) üretim ve istihdamda endüstri ve hizmet sektörünün gelişmesi, (3) kentte yaşayan nüfusun kırsal kesimde yaşayan nüfustan fazla olması, (4) kente özgü davranışların oluşması, (5) kitle iletişim araçlarının gelişmesi, (6) eğitim yatırımlarına önem verilmesi, (7) nitelikli iş gücünün artması, (8) kentte yaşanabilir ekolojik ve sosyal çevrenin oluşturulması ve (9) kentsel mekânların insan yaşamını kolaylaştıracak şekilde planlanması şeklinde sıralanmaktadır.

XX. yüzyılın en önemli kavramlarından biri olan kentleşme, toplumların ekonomik, politik ve kültürel hayatlarındaki köklü değişimleri içermektedir. Meydana gelen bu değişimler sonucu ekonomik hareketlenme ile birlikte, sosyal ve kültürel hayat canlanmış ve kentsel gelişim süreçleri başlamıştır. $\mathrm{Bu}$ sebeple, kentleşme ve gelişim kavramları birbirleri ile özdeşleşmiştir (Özkan, 2011).

Sanayi devriminden günümüze kadar olan süreçte kentleşme, İkici Dünya Savaşından sonra hızla tüm dünya ülkelerine yayılmaya başlamıştır. XX. Yüzyılın başlarında dünyada kentleşme oranı \%7 iken, hızla artış göstererek 1950 yılında \%29,1 seviyesine ulaşmış ve günümüzde \%50'leri aşmıştır (Karadağ, 2009).

\subsection{Hızlı kentsel gelişme ve etkileri}

Kentlerin oluşum sürecinde etkili olan faktörler, sanayileşmenin başlamasıyla birlikte, teknoloji ve iletişimdeki gelişmeler ve farklı üretim yöntemlerinin geliştirilmesiyle farklı boyut kazanmıştır. Kentlerin bu dönüşümü sonucunda, ekonomik ve ticari ilişkiler artarak kırsal kesimden göç almaya başlamıştır. Kentlerin mekânda hızlı büyümesi sonucunda kent merkezinden, kentin etrafında yer alan kırsal alanlara doğru bir yayılma olmuştur. Bu yayılma sonucunda doğal kaynaklar hızla tüketilmeye başlanmış ve plansız, çarpık yapılaşmalar meydana gelmiştir (Sezgin ve Varol, 2012).

Ekonomideki gelişmeler, gelir düzeyinin artmasıyla birlikte yükselen yaşam standartları, ulaşım imkânlarının gelişmesi ve ferah ve geniş mekânlarda yaşam isteği, kentsel yayılmanın en önemli sebeplerindendir.

Akseki ve Meşhur (2013), yapmış oldukları bir çalışmada kentsel yayılmanın ölçülmesinde; (1) yoğunluk, (2) kullanımlar, (3) ulaşım, (4) kent merkezi, (5) çekirdek oluşturma ve (6) kamu alanlarına yakınlığın ölçüt olarak kullanılabileceğini belirtmektedirler.

\subsection{Kentsel yayılmanın nedenleri}

Yakar (2013), XX. yüzyıldan itibaren başlayan kentleşme sonucunda kentlerin, kent merkezinin dışında yer bulmaya başladığını ve bunun sonucunda birbirinden kopuk yerleşim birimlerinin, boş araziler ile plansız bir yerleşim görüntüsünün ortaya çıktığını ifade ederek, kentlerin meydana getirdiği bu yeni oluşuma "Kentsel yayılma" adını vermiştir. Yine Yakar (2013), kentsel yayılma sebeplerini; (1) kent merkezindeki konutların merkez işleve dönüşmesi ve yüksek gelir gruplarının kent çeperlerine taşınması, (2) kent merkezindeki arazilerin sınırlı ve yüksek fiyatlı olması, (3) toplu 
konutlardaki gelişmeler, (4) artan konut ihtiyacı, (5) ekonomik ve teknolojik gelişmeler, (6) ulaşım ve iletişim ağının gelişmesi ve (7) arazinin sınırsız olarak görülmesi şeklinde özetlemektedir.

Kentsel yayılma ile birlikte, toprak, su ve enerji gibi kaynakların tüketimi artmakta ve sürdürülebilirlik tehlike altına girmektedir. Kent ekosisteminin bozulması çeşitli çevresel problemleri de beraberinde getirmektedir.

\subsection{Kentleşmenin çevre üzerindeki etkileri}

Kent, doğal çevre, insan ve insan hareketleri sonucu oluşan yerleşim biçimidir. Kentlerin oluşması ve kent formu kazanmas1, topografya, toprak, iklim, bitki örtüsü ve su kaynakları gibi bileșenlere bağlıdır. Hızlı nüfus artışına bağlı olarak kentlerin taşıma kapasiteleri artmakta, doğal çevre üzerindeki baskı ve tahripler çoğalmaktadır (Karadağ, 2009). Kentleşme biyolojik çeşitlilik kaybının çok önemli bir ön göstergesidir. Tabiatın kentleşmesi habitatın kaybı ve parçalanması ile ilişkilidir. Şehirleşme alanlarındaki, orman alanı gibi habitat alanları genellikle küçük ve düzensiz-şekilli ve yüksek çevre-alan oranına sahiptir (D. E. Davis, 2013). Tarım arazilerinin yerleşime açılması, kentsel yerleşimlerinin düzenlenmesinde ekolojik verilerin kullanılmaması plansız kentleşmeye yol açmaktadır (Kırz1oğlu, ve ark., 1999).

Kentleşmenin yerel türler üzerine etkileri ile ilgili çalışmalar yetersizdir. Fakat bu etkiler konusunda, tüm ekosistemler içindeki türlerin korunması hakkında son derece kentleşmiş insan nüfusunun eğitimi geliştirilebilir. Habitat kaybına sebep olan birçok insan faaliyetleri arasında yer alan kentsel gelişim, yerel türlerin büyük çoğunluğunda, yöresel neslin tükenme oranının artmasına ve çoğunlukla ortadan kalkmasına neden olur. Ayrıca kentleşme, habitat kaybının diğer tiplerinden daha kalıcıdır. Türler kentleşme ile ayrıca tarım, rekreasyon, yollar ve birçok diğer insan etkileri tarafından, kentsel yayılma ile birlikte benzersiz geniş kapsamlı dönüşümleri vurgulayan tehdit altındadır. Bu fiziksel değişiklikler doğal habitat kaybının kırsal kesimden kent merkezine doğru yükselen bir eğilimini ortaya koyar. Habitat kayboldukça daha çok sayıda ama daha küçük kalıntı yamalar halinde giderek daha parçalı hale gelir. Daha fazla yerel türlerin yaşayabilirliğinin artması ve kent merkezine doğru azalan kapsama oranı ile ilgili olarak habitat değişiminin dört tipi sırasıyla aşağıda verilmiştir.

- Yerleşik yaşam alanı: binalar ve kapalı yüzeyler, yollar gibi.

- Yönetilen bitki örtüsü: konut, iş merkezi ve diğer düzenli bir şekilde korunan yeşil alanlar.
- Çöplük veya atık alanlardaki bitki örtüsü: temizlenmiş fakat yönetilmeyen bir sürü boş alanlar, terkedilmiş çiftlikler ve diğer yeşil alanlar.

- Kalıntı doğal bitki örtüsü: asıl vejetasyondan adacıklar halinde kalan bitki örtüsü (daha ziyade yerel olmayan bitki istilasi).

Birçok konut ve ticari binaların imar yöntemlerinin yerel türler üzerinde tahrip edici etkileri yüzünden faal olarak gelişim gösteren bu alanlar düşük biyolojik çeşitliliğe sahip olma eğilimindedir. Birçok konut ve ticari binalar inşa edilmeden önce çoğunlukla bitki örtüsü ve üst toprağın uzaklaştırıldığı bilinir. Birçok çalışma, yerel olmayan türlerin sayı ve oranında kentsel-kırsal geçişi boyunca kent merkezine doğru bir hareketliliğin artma eğiliminde olduğunu göstermiştir. Kentleşme birçok çevresel sorunların hızlı bir şekilde artmasına neden olur. Kentleşmenin etkisi kentsel-kırsal geçiş üzerinde geliştiği ortaya konmuştur. Bu çalışmalar geçiş boyunca türlerin dağılımı ve tür zenginliği içerisinde kalıcı değişikliklerin olduğunu göstermiştir (McKinney, 2002).

Kentsel biyoçeşitliğin doğa ve türlerin korunması konusunda giderek artan kent nüfusunun eğitiminde önemli bir rolü vardır. Zira kentleşme, küresel ölçekte hızla yayılmaktadır. Koruma için temel bir güçlüğün biyoçeşitliliği nasıl etkilediğini anlamak lazımdır. Kentleşme yerel türlerin yok olmasının önemli bir nedeni olmasına rağmen, kentsel arazi kullanımının karmaşık yapısı yerel biyoçeşitlilik üzerinde karmaşık etkiye sahip olabilir. Bir yandan kentleşmenin bazı yönleri tür çeşitliliğinin azalmasını arttırmaktadır. Bunlardan birisi türalan etkisidir. Kent alanında geçirimsiz yüzeylerin geniş alanlara yayılması, bitki ve hayvanlar için kullanışlı alan kısmını azaltır. Diğer yandan, kentleşmenin bazı yönleri, genellikle kaybolan türlerden daha hızlı olarak yerel türlerin yerini alan yerel olmayan türlerin katılımı ile biyoçeşitlilik seviyesini artırıcı yönde destekleyebilir. Kentsel alanlar, birçok farklı arazi kullanımları ve küçük mekânsal ölçekte tercih edilen bitki yetiştiriciliği ile meydana getirilen son derece yüksek yerel habitat çeşitliliğine sahiptir (McKinney, 2008).

Biyoçeşitliliği korumak için sürdürülebilirlik ilkeleri benimsenmelidir. Sürdürülebilir tarım ve kırsal kalkınma kavramı Gündem 21'de gündeme getirilmiştir. Yine Birleşmiş Milletler DÇKK’nın 1992'de Rio de Jenario'daki konferansında bu konu ele alınmıştır. Özellikle sürdürülebilir tarım ve kırsal kalkınma, toprak kaynaklarının planlanması ve yönetimi konularında ciddi ölçütler ortaya konmuştur (Pezikoğlu, 2012). 
Kentleşme ile kuş topluluklarının üremesi üzerinde yapılan bir çalışma, kent çevresinin yoğunluğu ve türlerin zenginliği, doğal yaşam alanları için çok benzer olan yerel bitki örtüsü ile baskın olduğu ile kuş popülasyonlarının üremesi üzerine kentleşme etkisinin kentsel alanlarda yerel bitki örtüsünün kullanılması ile en azından k1smen de olsa azaltabileceğini ortaya koymuştur (Mills ve ark., 1989).

\subsection{Amaç dışı arazi kullanımı ve habitat par- çalanması}

Toprak fiziksel koşullarda üretilemeyen doğal bir kaynaktır. Kullanım amaçlarına göre, kentsel toprak ve tarımsal toprak olarak iki grupta incelenmektedir. Kentsel toprak, "Kentlerde üzerinde yap1 yapmaya ayrılmış ve kentin imkânlarından yararlanılabilen araziler" olarak tanımlanmaktadır. Tarımsal toprak, "Üzerinde tarımsal üretim yapılan ve verimliliği ile değeri ölçülebilen arazilerdir" (Ak1n, 2007).

Ülkemizde 1950'li yıllardan itibaren endüstrileşme ve hızlı nüfus artışı sonucunda kentleşme olgusu başlamıştır. $\mathrm{Bu}$ duruma bağlı olarak endüstri ve yerleşim alanları, yollar için gerekli olan araziler, özellikle tarım alanları için tehlike oluşturmaktadır (Yakar, 2013). Bunun yanı sıra enerji hatları, turistik alanlar, taş ocakları, spor tesisleri, hava alanları ve maden ocakları gibi yatırımlar da arazilerin amaç dışı kullanımında etkili rol oynamaktadır (Paksoy ve Direk, 1994). Amaç dışı alan kullanımına en önemli sebep, yeni yerleşim birimlerinin oluşmasıdır. Kent merkezinden çeperlere doğru yayılan ve kent çevresinde bulunan bağ, bahçe ve tarım alanları hızla yerleşim alanlarına dönüşmektedir. Bir örnek vermek gerekirse Ankara İli' nde 1969'da 3205 ha tarıma elverişli alan yerleşim alanı olarak kullanılmakta olup, 1992 yılında 19179 ha'a ulaşmıştır. Yine Ankara'dan örnek vermek gerekirse, Ankara-Eskişehir yol güzergâhındaki tarım alanlarının çoğu yerleşim etkisi altına girmiştir (Yakar, 2013).

Kentleşmenin en büyük sorunlarından birisi habitatın parçalanmasıdır. Fahrig (2003)'e göre habitat parçalanması genellikle habitat kaybı ve habitatın başka bir yere ayrılmasını kapsayan geniş arazi ölçeğindeki oluşum olarak tanımlanır.

Forman (1995), arazi ve bölgelerin ekolojisi adlı çalışmasında arazi parçalanmasının korunması için genel bir süreçte arazi dönüşümü için önemli etkileri olan alan, büyüklük ve şekil gibi tabiat ögelerinin parçalanmayı nasıl etkilediğini irdelemiş olup habitat parçalanmasının iki bileşeni olduğunu belirtmiştir. Bunlar; (1) doğa içerisinde bir habitat tipinin toplam miktarındaki azalma, (2) habitatın daha çok izole edilmiş parçalar içerisinde kalan küçük habitatların yeniden bölüştürülmesi.

Başka bir çalışmada habitat parçalanması, "önceden bitişik olan doğal ortamdan mekânsal ve ardışık yaşam alanlarının karmaşık bir mozaik oluşturması" olarak tanımlanmaktadır. Habitat parçalanması arazi boyunca yabani türlerin dağ1lımını ve beslenme, kur yapma, üreme ve göç gibi yaşam fonksiyonlarını değiştirir. Habitat parçalanmasının önemli nedenlerinden birisi de ulaşım ağlarıdır ve mevcut yollar ile bozulmuş olan yüzeylerin ötesinde yaban hayatı üzerinde olumsuz etkileri vardır. Habitat parçalanması hatta topografya ve vejetasyon çeşitliliği, yangın, dere yatağı akışı ve diğer doğal biyolojik ve fiziksel özellikler ve süreçlerdeki çok çeşitlilik nedeniyle geniş alanlarda kendiliğinden meydana gelir (Ecology and E.R.D., 2006).

Yollar habitat parçalanmasına önemli derecede katkıda bulunurlar çünkü yollar geniş arazileri küçük parçalara böler ve iç kısımdaki habitatları kenar habitatlarına dönüştürür. Ek olarak kereste üretimi için yapılan yollar da geniş araziler boyunca habitat parçalanmasını arttırır. Bazı türlerin popülasyonu tecrit edilir, yerel türlerin imhası ve yok olma tehlikesi artar (Watson, 2005).

\section{Materyal ve yöntem}

\subsection{Materyal}

$26.897 \mathrm{~km}^{2}$ 'lik alana sahip Ankara, Doğusunda Kırıkkale, batısında Eskişehir, kuzeyinde Çankırı ve güneyinde Konya komşu illerindendir (URL3). Çalışma alanı olan Yapracık-Bağlıca mahalleleri Etimesgut ilçesi sınırlarında yer almaktadır. Yapracık, Ankara'nın batısında Eskişehir yolu üzerinde olup merkeze uzaklığı 20 km'dir. Sınırı olan Bağlıca'nın ise merkeze uzaklığı 17 km' dir. (URL-4). Etimesgut İlçesi doğudan batıya doğru eğimi azalan bir çanak şeklindedir. İlçenin ortalama yüksekliği 807 m'dir (Etimesgut belediyesi, 2009). Çalışma alanı engebeli bir yapıya sahiptir. Araştırma alanındaki en yüksek alan $1250 \mathrm{~m}$ ile Meşe Dağıdır (URL-4). Çalışma alanı Şekil 1'de verilmiştir.

Çalışma alanı olarak Ankara ili sınırları içerisinde yer alan Bağlıca ve Yapracık mahalleleri seçilmiştir. Araştırmada kullanılan yardımcı materyaller şunlardır:

- $1 / 25000$ ölçekli topografik harita

- Belediye imar planları

- 1/50000 ölçekli hava fotoğraflar1

- 1/25000 ölçekli amenajman haritaları 
- İklim verileri

- Toprak haritaları

- Jeolojik etütraporlarıvealankullanım haritaları

- Alan fotoğrafları

\subsection{Yöntem}

Araştırmanın yöntemi Young ve Jarwis (2001) yöntemi esas alınarak kurgulanmıştır. Bu yöntemle, alandaki habitat parçaları hava fotoğrafları ve haritalama ile belirlenmiştir. Bu sınıflandırma yarı doğal alanlarda kente özgü detaylar ve mevcut kaynaklar göz önünde bulundurularak yapılmıștır. Geçmiş̧ten bugüne kadar olan kullanımlar göz önüne alınarak, bu alandaki habitatlara etkisi değerlendirilmiș ve geleceğe yönelik koruma ve kullanma önerileri getirilmiștir. 1950 y1lından itibaren elde edilen kent planları, tarım il müdürlüğünden elde edilen haritalar ve uydu görüntüleri sayısallaştırılarak veriler analiz edilmiştir. Tüm verilerin analiz edilmesinden sonra güncel alan kullanım haritaları oluşturulmuștur. Bu haritalara göre bölgenin önceki ve bugünkü durumuna yönelik planlama ve koruma önerileri getirilmiştir.

\section{Bulgular}

\subsection{Araştırma alanı ile ilgili genel bilgiler}

\subsubsection{Jeoloji ve jeomorfojoji}

Calıșma alanında çeșitli jeolojik formasyonlar bulunmaktadır. Araştırma alanı, killi kireçtaşı, marn, silttaşı ardalanmasından oluşan birim ve bu birimlerin üstünde ayrışma ürünü olan çakılll, kumlu, siltli killi birimden oluşmaktadır (ABB-2). Bunların dışında alanda bulunan diğer formasyonlar şunlardır: Gölbaşı Formasyonu; Konglomera, kumtaşı ve çamurtaşı, Bozdağ Bazalt; Bazalt, Tekke Volkaniti; Andezit, trakiandezit, tüf ve aglomera Alüvyon; Kum, çakıl (MTA, 1995).

Jeolojik yapının çeşitli olması, alandaki bitki türlerini ve yayılışlarını da etkilemektedir.

\subsection{2. İklim}

Çalışma alanı iklimi İç Anadolu Karasal İklim özellikleri göstermektedir. Yazlar sıcak ve kurak, kışlar soğuk geçmektedir. Kıș aylarında don olayı görülmektedir. Yağış en fazla kış ve ilkbahar aylarında düşmektedir (TUBITAAK, 2012). Hâkim rüzgâr yönü topografik yapıya bağlı olarak değişiklik göstermektedir. Çalışma alanında güneybatı yönlü rüzgârlar görülmekte olup, en sert rüzgârlar Mart ve Nisan aylarında görülmektedir (ABB-1). Doğal bitki örtüsü steptir.
Ankara sert iklim koşullarına sahip olduğundan dolayı, soğuk hava koşuları, don ve buz gibi etkilere dirençli, ayrıca tuza dayanıklı bitki türleri doğal yayılış göstermektedir. Araştırma alanı, topografik yapısından dolayı rüzgarlara açık bir alandadır.

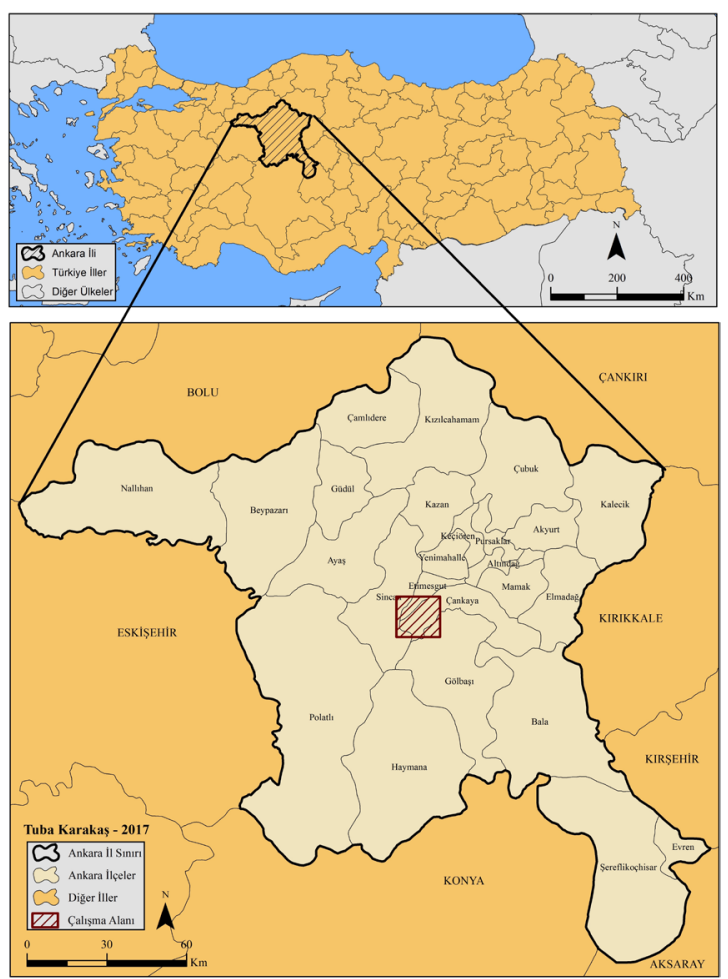

Sekil 1. Calıșma alanı

Figure 1. The field of study

\subsubsection{Arazi durumu ve toprak yapısı}

Çalışma alanı, Yapracık mahallesinde IV. sınıf, V. sinif ve IV. sinif toprak grubu ile VII. sinif toprak grubu bulunmaktadır. Bağlıca mahallesinde daha çok II. sınıf tarım arazisi, V. sınıf ve VI. sınıf ve VII. Sinıf toprak grubu bulunmaktadır. Burada bulunan II. sınıf mutlak tarım alanı, öncelikle korunması gereken alanlar arasında yer almaktadır. II. sınıf toprak grubu (mutlak tarım alanı), her türlü bitkinin yetişmesine imkân veren toprak grubudur. IV. sınıf alanlar, derinlik ve eğim açısından sınırlı özelliklere sahip olup, uygun sürüm yapılarak özel bitki türlerinin gelişmesine olanak vermektedir. V. sınıf ve VI. Sınıf toprak grupları, sürüm yapılamayan, taşlık ve taban suyunun yüzeye yakın olduğu sığ toprak gruplarıdır. Çayır, mera ve ağaçlık alan olarak kullanılabilmektedir. VII. sınıf topraklar, eğimli, taşlı ve erozyon riski yüksek gruplardır. Tarım için elverişli değildir (Yiğitbaşıŏglu, 2000).

Çalışma alanında genel olarak kahverengi kolüvyal topraklar ve kahverengi orman toprakları bulunmaktadır (Tarım il Müdürlüğü, 1992). Toprak 
yapısı incelendiğinde, her iki alan da, kuru tarım ve mera-otlak alanları için elverişlidir. Yapracık mahallesinde bunlara ek olarak orman-fundalık alanlar bulunmaktadır. Tarım arazilerinin dağılı- mında en çok payı buğday ve arpa gibi ürünlerin yetiştirildiği "tarla" alanları almaktadır. Çalışma alanının genel durumunu yansitan toprak profili Şekil 2'de verilmiştir

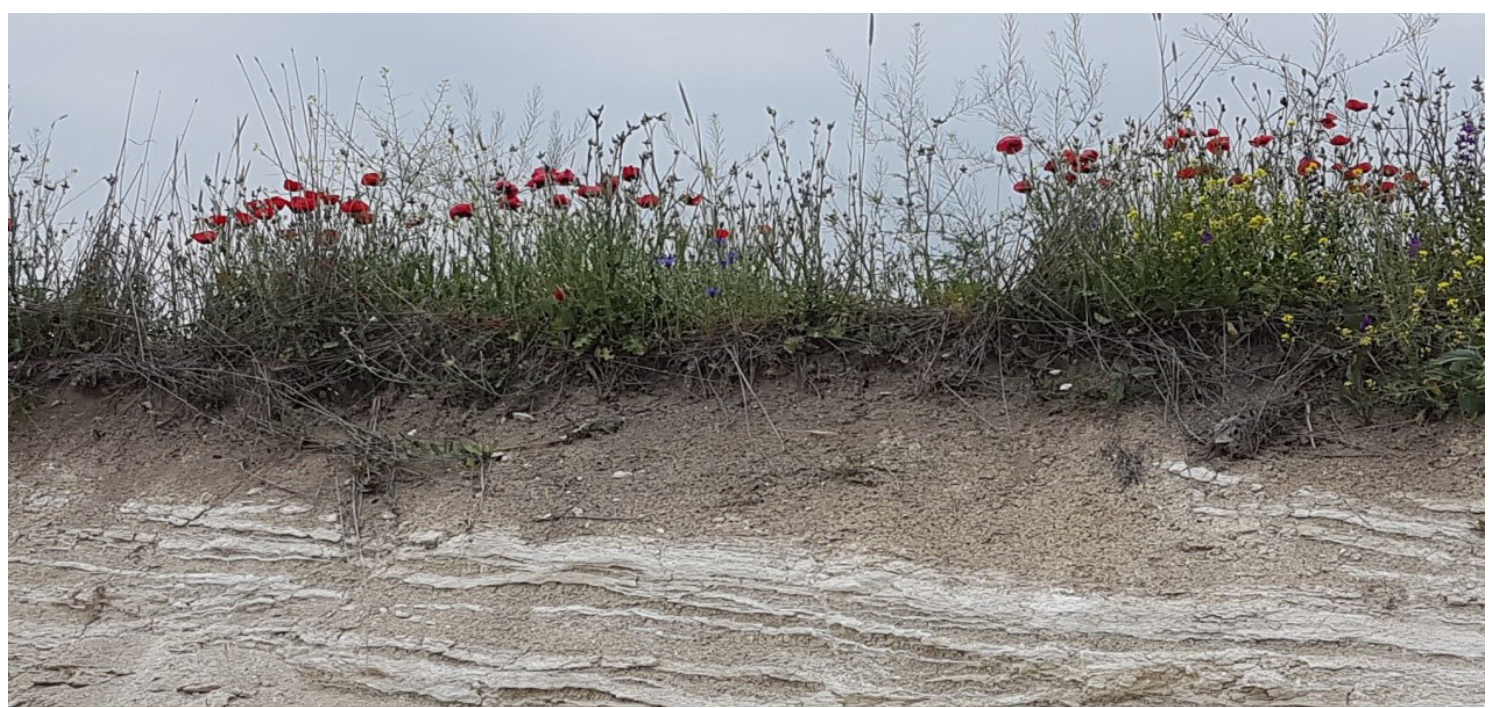

Şekil 2. Çalışma alanına ait yamaç toprak profili Figure 2. Slope soil profile of study area

\subsubsection{Flora}

Çalışma alanında mevcut flora oldukça çeşitlilik göstermektedir. Özellikle gramine türleri en fazla görülen bitki türleridir. Bununla birlikte Yapracık'ta yer alan meşe dağında çok fazla gelişme göstermeyen adeta çalı formunda bozuk meşe grupları yer almaktadır. Kuru ve sulu dere yataklarında kavak ve söğütler sıkça rastlanan bitkilerdir. Ayrıca akasya, iğde gibi yapraklı türler de görülen diğer yapraklı türlerdendir. Taban su

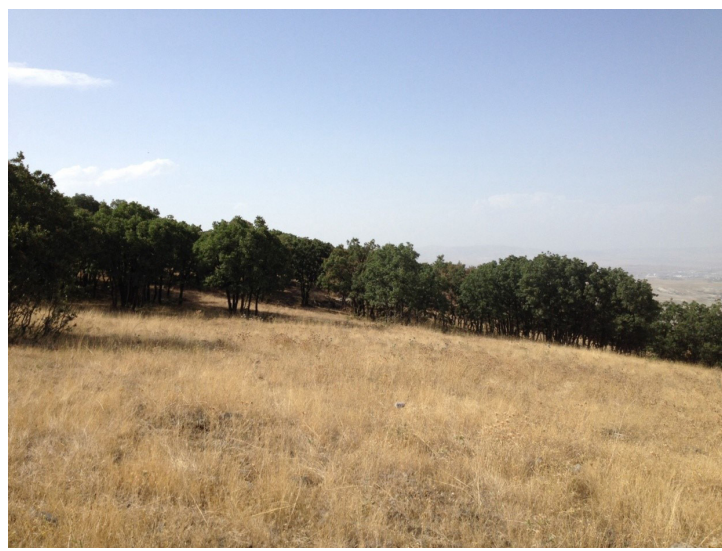

Şekil 3. Yapracık Meşe dağında yer alan meşe ormanı kalıntıs1

Figure 3. The remains of oak forest in Meşe Mountain at Yapracik seviyesinin yüksekte olduğu yerlerde juncus (Juncus spss.) türleri tespit edilmiştir. Çalışma alanımızı neredeyse ortadan ikiye bölen çevre yolu ile Ankara-Eskişehir yolunun kenarında ve şev yamaçlarında dikim yoluyla getirilmiş sedir (Cedrus libani A. Richard), karaçam (Pinus nigra J. F. Arnold), sürünen ardıç (Juniperus sabina L.) gibi türler yer almaktadır.

Çalışma alanında yer alan meşe ormanı kalıntılarına ve juncus türlerinin yer aldığ 1 alana ait resimler Şekil 3 ve Şekil 4’te verilmektedir.

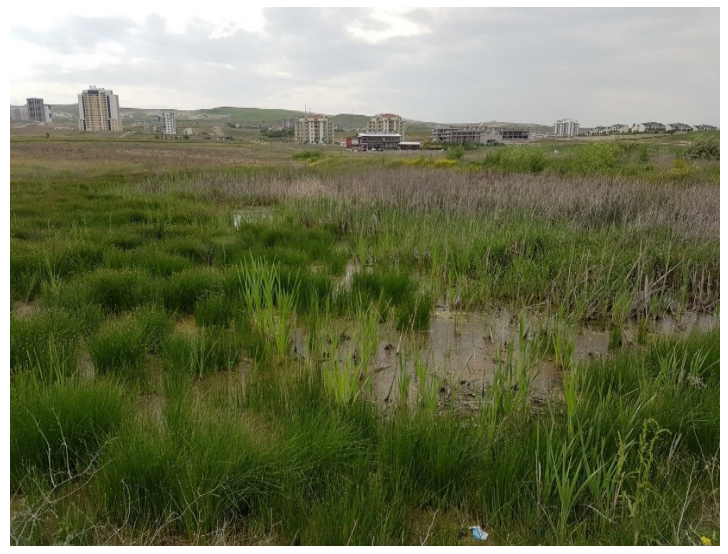

Şekil 4. Çalışma alanında juncus türlerinin yer aldığı bir alan

Figure 4. Some juncus species in study area 
Bununla birlikte çalışma alanında tespit ettiğimiz bazı bitki türleri aşağıda verilmiştir. Bu bitki türleri her iki alanda da yani Bağlıca ve Yapracık'ta tespit ettiğimiz bitki türleridir. Bu konuda yapılacak detaylı bir flora çalışması ile mevcut bitki türleri ve taksonları belirlenebilir.

Anthemis arvensis, Carduus spss., Carex spss., Euphorbia spss., Agropyron spss., Glaucium grandiflorum (boynuzlu gelincik), Plantago spss., Sonchus arvensis (tarla eşek marulu), Xanthium strumarium (küçük pıtrak), Bromus spss., Adonis aestivalis (kır lalesi), Phlomis armeniaca (anadolu alev otu), Phlomis pungens (yelotu), papaver somniferum (gelincik), Datura stramonium (boru çiçeği), Hyoscyamus spss., Vitex spss., Graminea spss., Centaurea spss., Cirsium spss., Xanthium spinosum (dikenli pitrak), Convolvulus arvensis (tarla sarmaşığı), Convolvulus lineatus (çizgili sarmaşık), Convolvulus sepium L. (çit sarmaşı̆̆1), Alyssum desertorum, Equisetum arvense (at kuyruğu), Aegilops spss., Alopecurus spss., Festuca spss., Poa spss., Hypericum spss., Gadious spss., Salvia divinorum (adaçayı),

Astragaus spss., Trifoium spss., Armeria spss., Poygonum spss., Rumex spss., Consoida orientais (tarla hazeranı), Ranuncuus spss. (düğün çiçeği), Gaium spss., Veronica persica (yavşan otu), Eryngium spss., Carum spss., Opopanax hispidus, Urtica dioca L. (1sirgan) ve Zosima spss.

Çalışma alanında yer alan bazı bitkilere ait resimler Şekil 5'te verilmektedir.
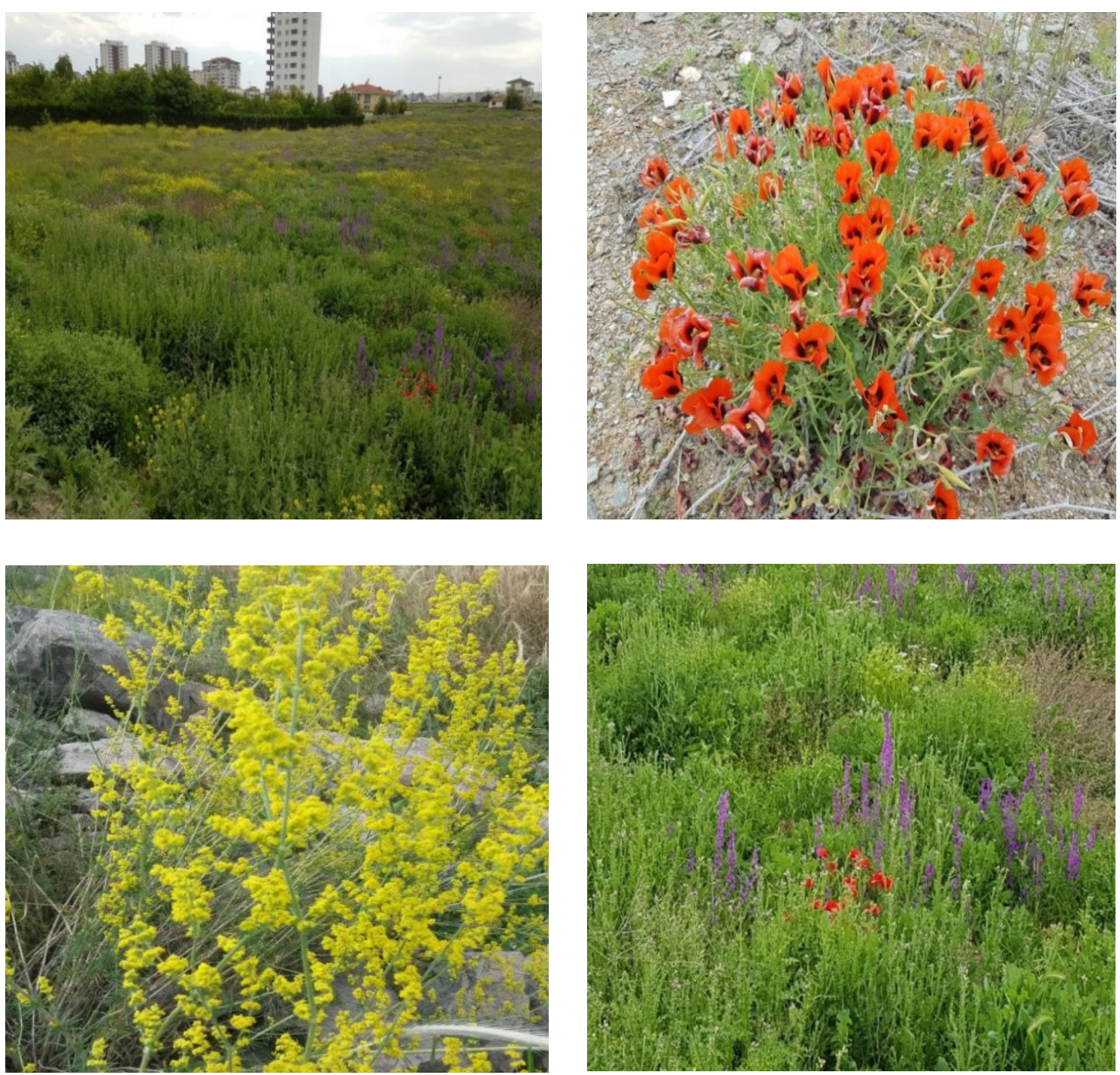

Şekil 5. Çalışma alanında yer alan bazı bitki türleri Figure 5. Examples some plant species at study area 
İster otsu bitkilerden olsun isterse odunsu bitkilerden olsun çalışma alanımızda yerel olarak bulunan türler dışında farklı türlerin de, karayolu ağaçlandırma çalışmaları, park ve bahçeler için yapılan ağaçlandırma çalışmaları, toplu konut ve ticaret alanlarında yapılan bitkilendirme

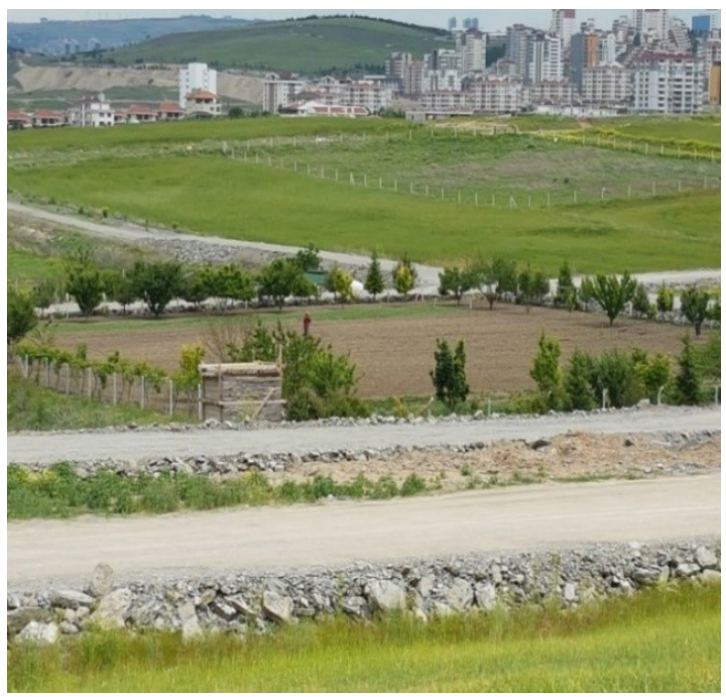

çalışmaları ile kullanıldıkları görülmüştür. Ayrıca bireysel olarak insanların kendileri için ayırdıkları küçük alanlarda (hobi bahçesi, kır evi gibi) farklı bitki türlerini de (meyve, çalı, ağaççık, ağaç) kullanarak kendilerine özgü bir peyzaj anlayış1 getirdikleri tespit edilmiştir (Şekil 6).

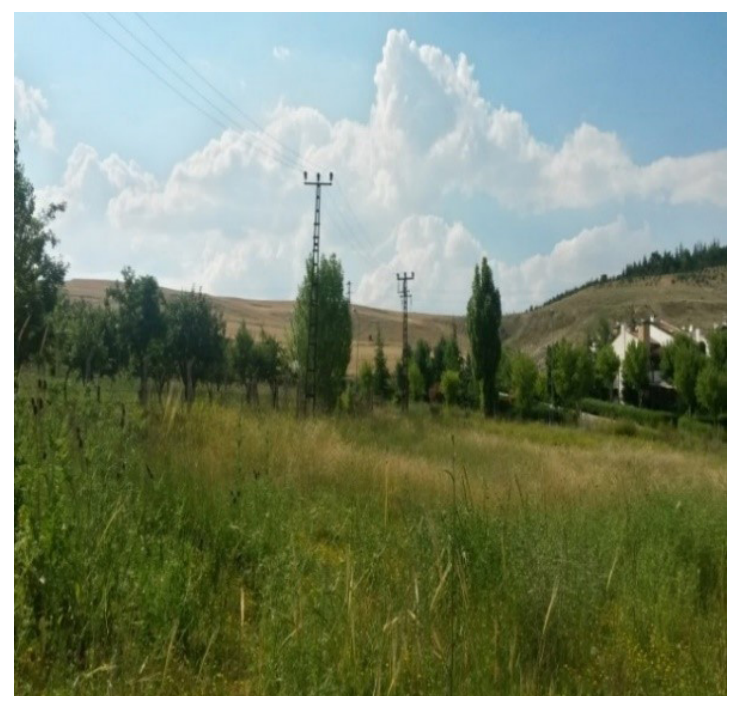

Şekil 6. Bahçe olarak ayrılmış bir alan Figure 6. A reserved field as a garden

Her ne kadar toplu konut, ticaret merkezleri ve yol yapımı gibi unsurların inşası ile mevcut alanlarda yer alan bitki örtüsünün azaltılması ile biyolojik çeşitlilik azalsa bile yukarıda belirtilen uygulamalar ile yerel türlerin dışında farklı türlerin de kullanılması suretiyle biyolojik çeşitliğin arttığ 1 da tespit edilmiştir. Çalışma alanında yer alan ağaç formundaki bitkilerin çap ve kapalılık durumuna göre yapılan gruplandırma Tablo 1'de verilmiştir.

Ankara-Eskişehir Yolu'nun çalışma alanı içinde kalan bir kısmı ağaçlandırma alanı olarak ifade edilmektedir. Ankara-Eskişehir karayolu ağaçlandırma çalışması örneği Şekil 7'de görülmektedir. Mevcut yer alan ağaçlık alan ise, korunacak alanlar olarak geçmekte ve D tipi kent ormanı olarak belirlenmiştir.

Tablo 1. Çalıșma alanındaki ağaç formundaki bitkiler Table 1 . Some tree species at study area

\begin{tabular}{lcc}
\hline Bitki türü & $\begin{array}{c}\text { Çapı } \\
(\mathrm{cm})\end{array}$ & $\begin{array}{c}\text { Kapalılık } \\
(\%)\end{array}$ \\
\hline Meşe & $0-8$ & 30 \\
Meşe & $8-16$ & 70 \\
Meşe & $16-24$ & 30 ' un altında \\
Karaçam & $0-16$ & 70 \\
Karaçam & $0-16$ & 70 'den fazla \\
Sedir + Karaçam & $8 \mathrm{~cm}$ 'den az & \\
Sedir + Karaçam & $8-16$ & 70 \\
\hline
\end{tabular}
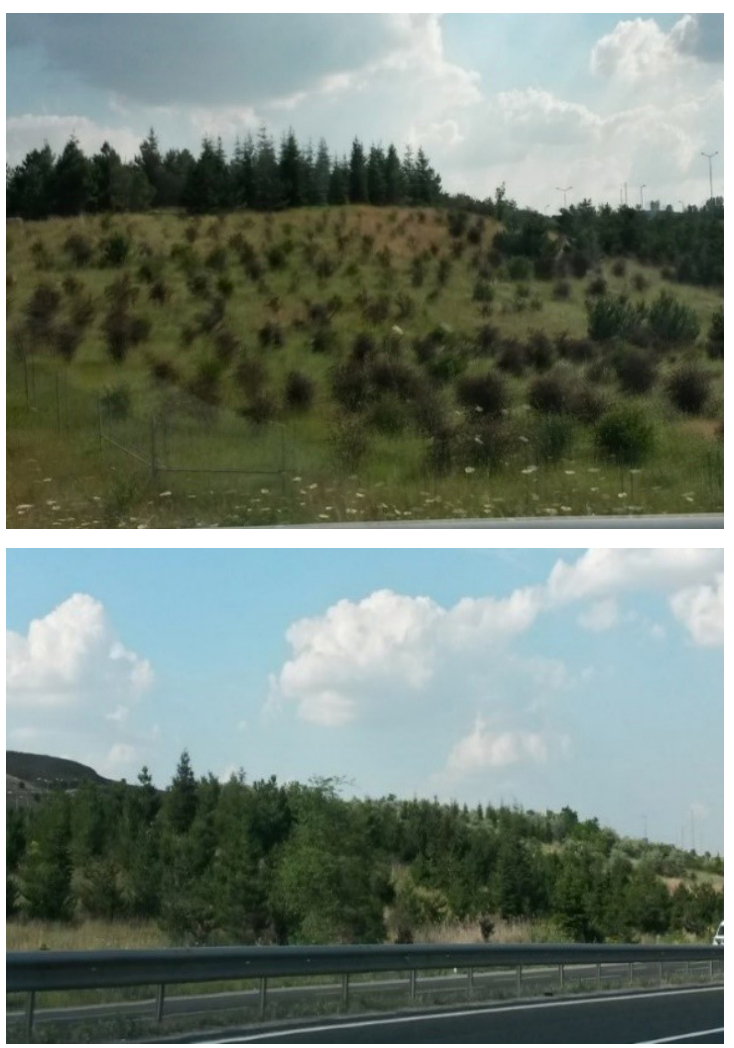

Şekil 7. Ankara-Eskişehir karayolu ağaçlandırma çalışması

Figure 7. Ankara-Eskişehir highway afforestations 


\subsubsection{Nüfus ve Demografik Yapı}

2000 yılı nüfus sayımına göre il nüfusunun \%83'ünün merkez ilçelere ait olduğu görülmektedir. Nüfusun geri kalanı ise kent merkezi dışında kırsal ve yarı kırsal alanlarda yaşamaktadır. Kent nüfusu 1920-2000 yılları arasında 100 kat artış göstermiştir. Hızlı artış ile birlikte, toplumsal ve mekânsal yapı da değişmeye başlamıştır. Nüfus artışı açısından Ankara'nın gelişme süreci 4 evrede incelenebilir:

1927-1950 yılları arası: Bu dönemde kentleşme hızı, nüfus artış hızının üzerindedir. Ankara Türkiye genelinden iki kat fazla hızla büyümektedir.

1950-1975 yıllarl arası: Bu dönemde hem nüfus hızı hem de kentleşme hızı, bir önceki döneme göre çok daha fazla artış göstermiştir.

1975-1990 yılları arası: Bu dönem kentsel nüfusun ve doğal nüfus artış hızının düştüğü gözlenmiştir.

1990-2000 yılları arası: Bu dönemde Ankara'da nüfus doygunluğa ulaşmış, kent merkezindeki nüfus kent çeperlerine doğru yayılmaya başlamıştır (ABB-1).

Y1llara göre dağılıma bakıldığında, kent merkezlerinde nüfusun hızla artması sonucunda, konut ihtiyacı artmış olup, kent merkezi çeperlere doğru genişlemeye başlamıştır. Bu durum kent çeperlerinde yer alan tarım alanı ve meralık alanların yerleşimin etkisi altında kalmasına sebep olmuştur.

2014 yılı nüfus verilerine göre, Yapracık mahallesi nüfusu 3920, Bağlıca mahallesi nüfusu 9922'dir. 2013 yılında hazırlanan planlarda, Bağlıca nüfusunun 105000, Yapracık ve Aşağıyurtçu nüfusunun 200000 olması öngörülmektedir (ABB-1).

\subsection{Ankara'nın Kentleşme Sürecinde Bağlıca ve Yapracık' in Yeri}

Ankara kentinin kentsel gelişim süreci özellikle Cumhuriyet dönemi ile birlikte hız kazanmıştır. $\mathrm{Bu}$ çerçevede Ankara kenti gelişimi planlama çalışmaları ve arazi kullanımları ile değerlendirilmiştir.

Lörcher Planı, Bugünkü Kızılay ve çevresini oluşturan, yol ve imar altyapısını oluşturan plandır.Kentin güneye doğru yönelmesinde etkili olmuştur. 1990 Nazım imar planı ile birlikte Etimesgut ilçesinde yer alan tarım toprakları yerleşime açılmıştır. Yaklaşık 55992 ha alan yerleşim merkezine dönüştürülmüştür (Sezgin ve Varol, 2012). 2025 planı ile Bağlıca ve Yapracık> 1 da içinde barındıran güneybatı bölgesi en önemli gelişim noktası haline gelmiştir.

\subsubsection{Bağlıca}

Etimesgut yerleşiminin güney aksı olarak belirlenmiş ve Büyükşehir Belediyesi tarafından planları hazırlanmış, bazı kısımlarında inşaat çalışmalarına başlanan alandır. 2023 planları ile 105000 nüfus öngörülmüştür (ABB-1). Etimesgut İlçesi yerleşim alanının güneyinde, batıda Çevre Yolu, doğuda Zırhlı Birlikler ve güneyde Eskişehir Yolu- Alacaatlı köyü ile sınırlanan 1640 ha alanda 1/50000 ölçekte "Bağlıca Köyü ve Çevresi Nazım İmar Planı” çalışması yapılmıştır. 1990 Nazım İmar Planı ile ele alınan, konut, spor alanları, üniversite kampüsleri, ağaçlandırılacak alanlar kararlar, 2025 Metropolitan Alan Nazım Planlama Çalışmaları ile hazırlanan planda tekrar gündeme getirilmiş ve bu kararların kullanımı önerilmiştir. Söz konusu planda, konut, üniversite alanları, bölgesel taleplere hizmet edebilecek merkez ve sosyal donatılarla desteklenecek "Kentsel Gelişme Alanı" önerilmektedir

- Eskişehir Yolu koridorunda üst gelir gruplarına hitap edecek, kentsel, sosyal ve teknik altyap1ya sahip yerleşim alanlarının geliştirilmesi,

- Bölgeye artan taleplerin ve kentsel yayılmanın denetim altına alınması,

- Koruma-kullanım kararlarının geliştirilmesi,

- Mekânsal kullanımlar, nüfus ve yoğunluk planlamaları ve ulaşım sistemleri planlanmıştır.

\begin{tabular}{lcc}
\hline Kullanım türü & $\begin{array}{c}\text { Alan } \\
\text { büyüklüğü } \\
\text { (ha) }\end{array}$ & Oranı \\
\hline Konut gelişme bölgesi & 290,0 & 17,6 \\
Kentsel spor alanı & 89,7 & 5,5 \\
Ağaçlandırma alanı & 31,9 & 1,9 \\
Kamu kuruluş alanı & 40,0 & 2,4 \\
Fuar-Festival alanı & 34,3 & 2,1 \\
Üniversite kampüs alanı & 1014,3 & 61,8 \\
Kentsel servis alanı & 32,1 & 2,1 \\
Yollar & 107,7 & 6,6 \\
\hline Toplam & 1640,0 & 100,0 \\
\hline
\end{tabular}

Tablo 2. Planlanan alan kullanımı Table 2. Planned land use 


\subsubsection{Yapracik}

Çalışma alanı, Ankara-Eskişehir Çevre Yolu'nun kuzeyinde kalan mevkiidir. $\mathrm{Bu}$ bölge ve yakın çevresinin imar çalışmaları tamamlanmış olup, Bağlıca ve Yapracık TOKİ planı arasında kalan tek imarsız bölümdür. Planlama alanı büyüklüğü 1030 ha'dır. Alanda yer alan ormanlık alanlar koruma altında bulunmaktadır. İl Gıda, Tarım ve Hayvancılık Müdürlüğü’nün 06.01.2011 tarihli 56916 sayılı ve 21.01.2013 tarihli 1819 sayılı yazısında Çaldağ Mevkii'nin marjinal tarım arazisi içinde kaldığ 1 belirtilmiş, 02.01.2013 tarihli 573307 sayılı yazısında ise, tarım dışı amaçla kullanımının uygun olduğu belirtilmiştir.

Yapracık-Aşağı Yurtçu bölgesine ait bazı öneriler getirilmektedir. Bölgeye ilişkin kararlar alınırken Bayındırlık ve İskân Bakanlığı'nın hazırladığı planlar ve alanın morfolojik yapısı göz önüne alınmıştır. Bölgeye ilişkin stratejiler şu şekildedir:

- Eskişehir Yolu kent girişinde itibaren bu aks boyunca prestij alanların oluşturulması,

- Konut alanlarında kentsel tasarıma dayalı planların geliştirilmesi,

- Açık-yeşil alan sistemlerinin oluşturulmasında topografik etmenler ve su yüzeyleri dikkate alınmalı ve bu alanlar yerleşimin olumsuz etkilerinden korunmalı,

- Ulaşım sisteminde Eskişehir Yolu'na alternatif yeni sistemler oluşturulmasıdır.

Planlama alanının yoğun yapılaşma baskısı altında olduğu görülmektedir. Alanın gelişme aksında yer alması, gelişen ve gelişmekte olan yerleşim alanlarına yakın olması ve üniversite kampüslerine yakın olması sebebiyle, konut talebinin yüksek olduğu bölgedir (ABB-2).

\begin{tabular}{lr}
\hline Mülkiyet & Alan $\left(\mathrm{m}^{2}\right)$ \\
\hline Maliye & 908.909 \\
Toki & 673,457 \\
Şahıs & 5.760 .768 \\
Orman & 807.530 \\
Tescil harici & 331.310 \\
Imarlı (köyiçi) & 1.806 .417 \\
Tüm alan & 10.288 .391 \\
\hline
\end{tabular}

Tablo 3. Planlama alanı mülkiyet durumu Table 3 The ownership status of planning areas

\section{Tartışma ve Sonuç}

Kentleşmenin hızlanması ile birlikte kentlerdeki yaşam alanları kent çekirdeğinden dışarı doğru bir gelişim göstermektedir. Bu gelişme daha ziyade kent merkezinden kırsala doğru olmaktadır. Bununla birlikte bu gelişim coğrafik şartlara göre kısitlanmakta ve daha az engebeli yerlere doğru uzanmaktadır.

Çalışma alanının da yer aldığı ve önümüzdeki yıllar için nüfusunun 100.000 üzerinde olması planlanan Bağlıca ve Yapracık yerleşim yerleri bu gün itibarıyla gittikçe kentleşme ve banliyöleşmenin etkisi altında kalmaktadır ve bu sürecin önümüzdeki yıllarda da devam etme eğiliminde olduğu gözlemlenmektedir.

Gölcük (2010), bir çalışmasında kentlerin mekânsal gelişimini iki eş zamanlı durumda ifade ederek bunların (1) kentlerdeki nüfusun hızla artması ve (2) kentsel yayılma ve kent formunun değişmesi olarak tanımlamaktadır. Bu tespit çalışma alanı ile birebir örtüşmektedir.

Kentleşme ile birlikte habitat birbirinden bağımsız ve daha küçük alanlar şeklinde parçalanmaktadır. Çalışma alanında yerlerde her ne kadar boylu orman ağaçları bulunmasa da otsu bitkiler bakımından oldukça zengin sayılabilir. Orman niteliğinde olup da çok fazla gelişim göstermeyen ve ormancılık literatüründe "bozuk" terimi ile ifade edilen yapı sadece Yapracık yerleşim alanının meşe dağında küçük gruplar halinde yer almaktadır.

Hardman (2011), kentlerin büyümesi ile birlikte yaşayan habitatların yok olduğunu veya karmaşık ekolojik toplumları destekleyen ama yeterince büyük olmayan alanlar şeklinde parçalandığını bildirmektedir. Bu durumu yine Hardman (2011), çalışmasında örnek olarak İngiltere'de insan nüfusu yoğunluğunun ve kent gelişiminin artması neticesinde kentleşmiş alanların çevirdiği ilçelerde nesilleri tükenen nadir bulunan bitki türlerinin \%35'inin azalmasına sebep olduğunu belirterek benzer şekilde Amerika Birleşik Devletleri'nde kentleşmenin, 275 türün tehlikeye girmesinden doğrudan doğruya sorumlu olduğunu bildirilmiştir.

Hardman'ın yukarıda ifade ettiği parçalanma ve bitki türlerinin yok olması ile karşı karşıya kalınacağı aşikardır. Çalışma alanında zırhlı birlikler olarak isimlendirilen askeri alanda büyük guruplar halinde karaçam toplulukları yer almaktadır (Şekil 8).

Bugün itibarı ile bu ağaç topluluklarının zarar görme ihtimali bulunmamakla birlikte, kentleşmenin günden güne geliştiği ve yayıldığı çalışma alanında bu geniş alanın da zaman içerisinde yerleşime 
açılabileceği veya büyük bir rekreasyon alanı olarak korunabileceği öngörülmektedir.

Kentleşme sadece habitatın parçalanarak azalmasına yol açmamakta aynı zamanda verimli üst toprağın taşınarak ortamdan uzaklaşmasına da sebep olmaktadır. Çalışma alanında yapılan incelemeler neticesinde ister konut yapım alanlarında olsun ister ise ticaret merkezlerinin inşasında olsun yol yapım çalışmalarına yoğun olarak rastlanılmıştır. Yol yapımında ise üst toprak kazınmayıp yalnızca dolgu yapılmak suretiyle yol yapımı gerçekleştirilmektedir (Şekil 9).

Cushman ve arkadaşları (2009), yaptıkları bir çalışmada arazi kullanımından kaynaklı habitat kaybının ve yollardan kaynaklı habitat bölünmesinin k1smi öneminin, söz konusu arazideki; habitat gereksinimlerinin, organizmaların yayılış kabiliyetlerinin, yolların biçimi ve arazi kullanımları arasındaki etkileşimlerebağlıolduğunuifade etmektedirler. Çalışma alanında yapılan yol çalışmaları yukarıda ifade edilen hususu teyit eder durumdadır.

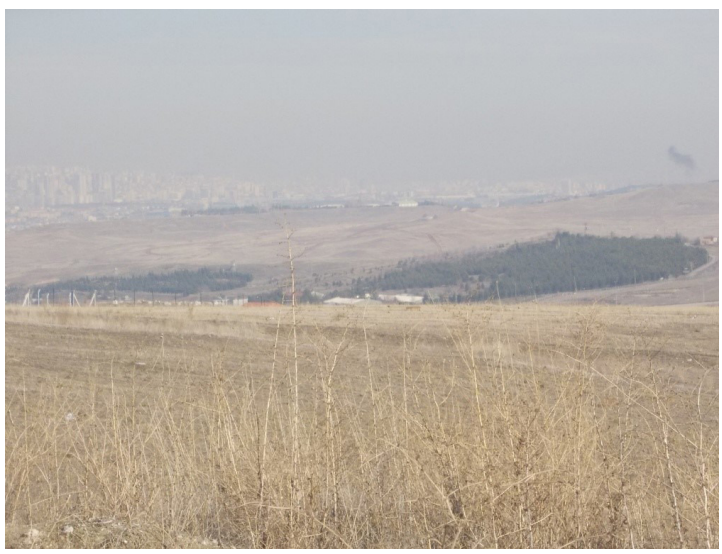

Şekil 8. Zırhlı Birlikler içerisinde kalan ağaç grupları Figure 8 . Tree groups in the military field

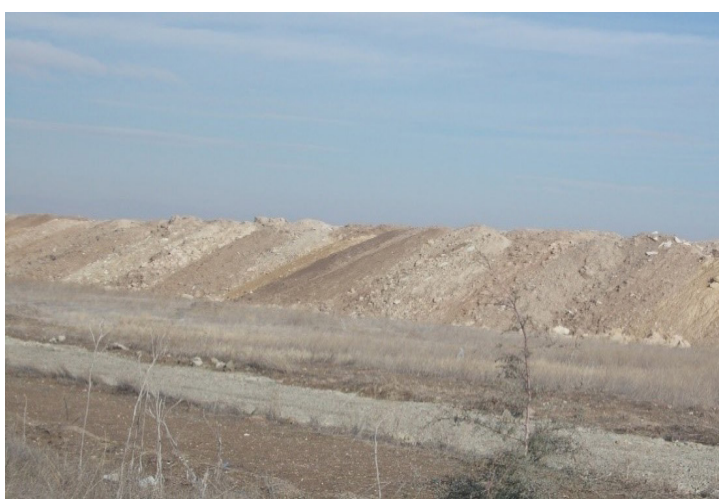

Şekil 9. Yol yapımı amacıyla yı̆̆ı̆lmış topraklar Figure 9. Superimposed soils for road building
Bağlıca ve Yapracık yerleşim alanları kentleşme ve banliyöleşmenin çok büyük etkisi altındadır. Günden güne konut ve ticaret merkezleri yapımı hızla devam etmektedir. Önceleri köylüler tarafından buğday, arpa gibi tarım ürünleri yetiştirmek için kullanılan bu alanlar üzerinde şimdi yüksek katlı yerleşim alanları ile geniş alanlara yayılmış ticaret merkezleri inşa edilmektedir. Öyle ki geçmişte köylüler tarafından da ifade edildiği üzere geniş bağ alanlarının bulunması suretiyle adını buradan alan "Bağlıca" (Şekil 10) günümüzde tam bir metropolitan olma yolunda hizla ilerlemektedir.

Robertson ve Swinton (2005), bir çalışmasında tarımsal dönüşümün, kentleşme/banliyöleşmenin artması ile birlikte doğal ekosistemlerin ve bunların bitki ve hayvan tür bileşeni üzerinde eşi benzeri görülmemiş zorluklar meydana getirecek demektedir. Bağlıca ve Yapracık'ın durumu yukarıdaki çalışmada yer alan hususları ifade etmektedir.

Çalışma alanında habitat üzerinde kentleşmenin etkisini tam anlamıyla görmek mümkündür. Geniş alanlara yayılan tarım alanları ve mera sahalarının yerinde yukarıda da ifade edildiği gibi binalar yükselmektedir. Tarım alanları dışında kalan çayırlık ve mera alanlarında yaptığımız tespitlere göre bol miktarda otsu türler bulunmaktadır. Bununla birlikte taban suyu seviyesinin yüksek olduğu yerlerde küçük gruplar halinde juncus'lara rastlanılmıştır. $\mathrm{Bu}$ alanlardaki habitatın parçalanarak yok olmasını tam olarak öğrenebilmek için uzun zamana ihtiyaç duyulacaktır. Ancak çalışmamızda habitatın parçalanarak mevcut tür sayısında azalmaların olduğu yapılan incelemeler neticesinde tarafımızdan tespit edilmiştir.

Yine yol yapımı amacıyla toprak yüzeyinin moloz, taş, kaya ve toprak gibi malzemeler kullanılarak doldurulması neticesinde, o toprak yüzeyinde kalan ve kilometrelerce uzunluk içerisinde yer alan bitki türleri de yok olmuştur. Bu şekilde yapılan uygulamalar neticesinde de birçok bitki türü zarar görerek tür zenginliği ve çeşitliliğinin azalmasına neden olmaktadir.

Çalışma alanında yer alan Bağlıca ve Yapracık, Ankara'nın genişleyip yayılmasına paralel olarak kentleşmenin etkisi altındadır. Ankara kentinde yer alan ticaret ve sanayi kuruluşları ile organize sanayi bölgeleri ve bunların sayılarındaki artışla birlikte kent nüfusu daha da artış gösterecektir. Kent nüfusunun artması ile birlikte yeni yerleşim alanlarının da kurulması kaçınılmazdır. Bu kapsamda; 2014 y1lı nüfus verilerine göre, Yapracık mahallesi nüfusu 3.920, Bağlıca mahallesi nüfusu 9.922'dir. 2013 yılında hazırlanan planlarda, Bağlıca nüfusunun 105.000, Yapracık ve Aşağ1 Yurtçu nüfusunun 
200.000 olması öngörülmektedir (ABB-1). Bu öngörüler kapsamında Bağlıca ve Yapracık'ın kentleşme veya banliyöleşme sürecinde ne kadar baskı altında kalacağı apaçık görülmektedir.

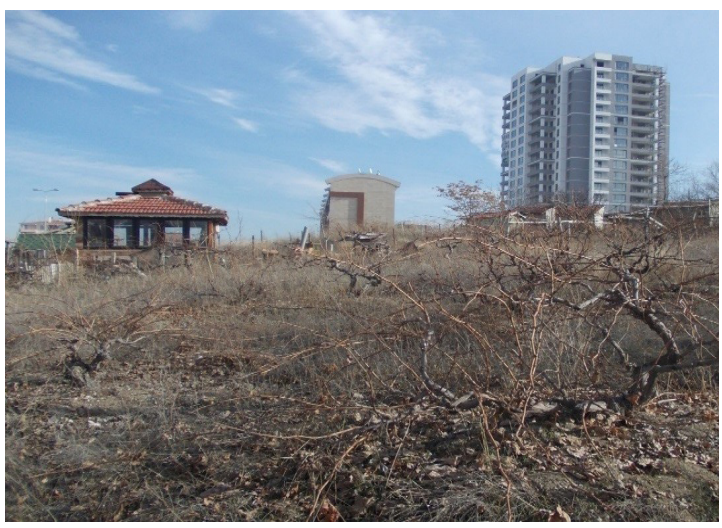

Şekil 10. Çalışma alanında yer alan bağ kalıntılarından bir görünüm

Figure 10. A view from the ruins of the vineyard

Sonuç olarak kentleşme ile birlikte büyük bask1 altında kalan habitatın parçalanarak azalması ve mevcut alanlar içerisinde kalan habitat tür ve zenginliğinin azalmasını önlemek amacıyla aşağıda sıralanan hususlar önerilmektedir;

- Yol yapımı suretiyle parçalanan habitatları birbirine bağlayan alt geçitlerin yapılması. Böylece sürüngenler ve memeli hayvanların yaşam alanları küçük parçalara ayrılmayacak, ayrılsa bile bu tür geçitler ile o türe ait nüfusun bir yerden diğer yere olan hareket kabiliyetleri artacaktır.

- Kentleşme ile birlikte konut ve ticaret merkezleri içerisinde kalan alanlarda yapılacak olan peyzaj çalışmalarında mümkün olduğunca o yörede yer alan bitki türlerinin kullanılması. Böylece, yerelde mevcut olan türler muhafaza edilmiş olacaktır. Ayrıca yapılacak peyzaj çalışmalarında kullanılacak diğer bitki türleri ile bu alanların tür zenginliği artmış olacaktır.

- Çok büyük alanların rekreasyon amaçlı ayrılması. Böylece, sadece insanların tıklım tıklım doldurduğu park ve bahçe anlayışından uzak, doğada mevcut olan yaban hayatının da bu rekreasyon alanında yer alması sağlanarak habitatın korunması sağlanacak ve türlerin zenginliği arttırılmış olacaktır.

- Konut ve ticaret merkezleri alanı dışında kalan boş ve atıl durumda bulunan arazilerin hafriyat, çöp atım alanı vb gibi durumlar amacıyla kullanılmaması. Böylece bu alanlar bu gibi atıklar ile doldurulmayıp hem toprağın kirlenmesinin önüne geçilecek hem de bitki ve hayvan türleri rahatsız edilmeden hayatlarına devam edecektir.

\section{Teşekkür}

Bartın Üniversitesi Orman Fakültesi Fen Bilimleri Enstitüsü tarafından Yüksek Lisans tezi olarak kabul edilen bu çalışmanın her aşamasında değerli katkılarda bulunarak beni yönlendiren değerli hocam Yrd. Doç. Dr. Yeliz SARI NAYİM'e tezimde kullandığım materyallerin temininde katkıda bulunan OGM personeline, Ankara Büyükşehir Belediyesi ve Etimesgut Belediyesi çalışanlarına ve herzaman desteğini ve yardımını aldığım Ahmet KARAKAŞ' a da teşekkürlerimi sunmayı borç bilirim.

\section{Kaynaklar}

\section{ABB-1. 2023 Başkent Ankara Nazım İmar Planı.}

ABB-2. Etimesgut İlçesi Yapracık Mahallesi Eskişehir Yolu Kuzeyine Ait 1/5000 Ölçekli Nazım İmar Planı Açıklama Raporu

Akın, E. (2007). Kentsel gelişme ve kentsel rantlar: Ankara örneği. doktora tezi. Ankara Üniversitesi sosyal bilimler enstitüsü, kamu yönetimi ve siyaset bilimi fakültesi. Kent ve çevre bilimleri anabilim dalı. Ankara

Akseki, H. ve Meşhur, Ç. M. (2013). Kentsel yayılma sonucu yapılaşmaya açılan verimli tarım alanları: Konya kenti deneyimleri. Megaron 2013, 8 (3): 165 174. DOİ:105505/Megaron 2013. 99609, Cilt Vol. 8, Sayı No 3.

Cushman, S. A., Compton, B. W. and McGarigal, K. (2009). Habitat fragmentation effects depend on complex interactions between population size and dispersal ability: Modelling influencesof roads, agriculture and residential development across a range of life-history characteristics. Spatial complexity, informatics and wildlife conservation. DOI 10.1007/9784-431-87771-4_20. Springer 2009.

Davis, D. E. (2013). Exploring the effects of urbanisation on biodiversty in remnant forests of the Charlotte metropolitan region. Master's of science in earth science. University of North Carolina at Charlotte. April 112013.

Ecology and E.R.D., (2006). Habitat fragmentation from roads: Travel planning methods to safeguard bureau of land management lands. Ecology and economics research department. The wilderness society. May 2006. Number 2.

Fahrig, L. (2003). Effects of habitat fragmentation on biodiversity. Annu. Rev. Ecol. Syst. 2003. 34:487-515. DOI:10.1146/annurev. ecolsys.34.011802.132419. Annual Reviews. 14 August 2003.

Forman, R. T. T. 1995. Land mosaics: the ecology of landscapes and regions. Cambridge University Press, Cambridge, UK. 
Gölcük, A. (2010). Kentsel planlama sürecinde kent formundaki değişimlerin Diyarbakır kenti örneğinde araştırılması. Yüksek lisans tezi. Çukurova Üniversitesi Fen Bilimleri Enstitüsü Peyzaj Mimarlığı Anabilim Dalı, Adana.

Hardman, S. (2011). How does urbanisation affect biodiversity. İn biodiversity 6 November 2011.

Karadağ, A. (2009). Kentsel ekoloji: Kentsel çevre analizlerinde coğrafi yaklaşım. Ege coğrafya dergisi, 18/(1-2), 31-47, İzmir.

Kırzıŏglu, M., I., Yılmaz, H., Yılmaz, S. (1999). Ekolojik temele dayalı kentleşme-çevre etkileşimi. Atatürk Üniversitesi Ziraat Fakültesi Dergisi, 30 (2), 187-191

McKinney M. L. (2002). Urbanisation, biodiversity and conservation. Bioscience 883-890. Vol. 52. No. 10. October 2002.

McKinney, M. L. (2008). Effects of urbanisation on species richness: A review of plants and animals. Urban Ecosyst. 2008. 11:161-176. DOI 10.1007/s11252007-0045-4.

Mills, G. S., John, B., Dunning, JR. and Bates, J. M. (1989). Effect of urbanisation on breeding bird community structure in southwestern desert habitats. The Condor91: 416-428. The Cooper Ornithological Society 1989.

MTA, (1995). Ankara F-15 paftas1 jeoloji haritas1, Maden Tetkik ve Arama Genel Müdürlüğü.

Özkan, S. (2011). Ankara'da kentleşme sürecinde konut sorunu. Yüksek lisans tezi. Gazi Üniversitesi Sosyal Bilimler Enstitüsü, Kamu Yönetimi Anabilim Dalı, Kentleşme ve Çevre Sorunları Bilim Dalı, Ankara.

Paksoy, M. ve Direk, M. (1994). Tarım alanlarının tarım dışı amaçlarla kullanılması. Ekoloji Çevre Dergisi, Ekim-Kasım-Aralık, Sayı:13.

Pezikoğlu, F. (2012). Sürdürülebilir tarım ve kırsal kalkınma kavramı içinde tarım-turizm-kırsal alan ilişkisi ve sonuçları. KMÜ Sosyal ve Ekonomik Araştırmalar Dergisi 14 (22): 83-92, ISSN: 1309-9132.

Robertson, G.P. and Swinton, S.M. 2005. Reconciling agricultural productivity and environmental integrity: a grand challenge for agriculture. In: Frontiers in Ecology 3,38-46.

Sezgin, D. ve Varol, Ç. (2012). Ankara'da kentsel büyüme ve saçaklanmanın verimli tarım topraklarının amaç dışı kullanımına etkisi. METU FJA 2012/1 (29:1), 273-288 DOI: 10.4305

Tarım İl Müdürlüğü, (1992). Tarım, Orman ve Köyişleri Bakanlığ1 Köy Hizmetleri Genel Müdürlüğü Yayınları, Ankara ili arazi varlığı, il rapor no:06. Etimesgut İlçe Tarım Müdürlüğü, 2015.
TÜBİTAK, (2012). Biyolojik çeşitlilik-doğa koruma ve sürdürülebilir kalkınma. Vizyon 2023 Ankara ili Etimesgut ilçesi, Yapracık Köyü Bağlar mevkii imar planına esas jeolojik ve jeoteknik etüt raporu, 2012, Ankara.

Ulusoy, A. ve Vural, T. (2001). Kentleşmenin sosyoekonomik etkileri. Belediye Dergisi, Cilt:7, Sayı:12.

(URL-1).https://sehirplanciligi.wordpress. com/2013/04/21/kent-nedir/

(URL-2).https://www.google.com.tr/url?sa=t\&rc $\mathrm{t}=\mathrm{j} \& \mathrm{q}=\&$ esrc $=\mathrm{s} \& \operatorname{source}=$ web \& $\mathrm{cd}=12 \& \mathrm{ved}=0 \mathrm{C}$ FMQFjALahUKEwiL7ojDkK7IAhUKXCwKH bilC $8 \&$ url =http $\% 3 \mathrm{~A} \% 2 \mathrm{~F} \% 2 \mathrm{Fwww}$.yildiz.edu. tr\%2F ealtinok $\% 2$ Fkentlesme.ppt\&usg=AFQjCNE W6534sRXbvJzgTC21notN3iOOuQ\&bvm=bv.104317 490,d.bGg\&cad $=$ rja

(URL-3).http://www.ankarakultur.gov.tr/servisler/genel-bilgiler/cografi-konumu

(URL-4). https://tr.wikipedia.org/wiki/ Ba\%C4\%9Fl\%C4\%B1ca, Etimesgut

Van Der Ree, R., Clarkson, D. T., Holland, K., Gullu, N. And Budden, M. (2008). Review of mitigation measures used to deal with the issue of habitat fragmentation. Australian Government. Final Report 2008.

Wade, M.R., Gurr, G.M. and Wratten, S.D. (2007). Ecological restoration of farmland: progress and prospects. In: Philosophical Transactions of the Royal Society, Series B. 363, 831-847.

Watson, M. L. (2005). Habitat fragmentation and the effects of roads on wildlife and habitats. Conservation Services Division New Mexico Department of Game and Fish. January 2005.

Yakar, A. (2013). Kentsel gelişme alanlarında arazi kullanımı ve değişiminin sürdürülebilir arazi yöntemi açısından incelenmesi: Trabzon ili örneği. Yüksek lisans tezi. Karadeniz Teknik Üniversitesi Fen Bilimleri Enstitüsü, Harita Mühendisliği Anabilim Dalı, Trabzon.

Yiğitbaşığlu, H. (2000). Türkiye'de tarım topraklar1nın kullanımında yapılan başlıca yanlışlıklar ve bunlara bir örnek: Eskişehir. Ankara Üniversitesi Dil ve Tarih-Coğrafya Fakültesi Dergisi, 40, 3-4(2000), 3-12.

Young, C. ve Jarwis, P. (2001). Measuring urban habitat fragmentation: an example from the Black Country, UK, Landscape Ecology 16: 643-658, 2001. Kluwer Academic Publishers. Printed in 